\title{
Effect of deficit irrigation on yield and yield components of sunflower on Gezira clay soil, Sudan
}

\author{
E. R. A. Elsheikh ${ }^{1}$, B. Schultz ${ }^{2}$, A. M. Haili ${ }^{2}$ \& H. S. Adam ${ }^{3}$ \\ ${ }^{1}$ UNESCO-IHE Institute of Water Education, The Netherlands \\ ${ }^{2}$ Core Land and Water Development, UNESCO-IHE, The Netherlands \\ ${ }^{3}$ ARC-WadMedani, Sudan
}

\begin{abstract}
Sunflower has become an important crop for both farmers and consumers in Sudan. It is a crop that fits well in the local cropping system and is considered to be the second most important oil crop after groundnut of the country. Regular irrigation intervals could be reduced in order to increase total yield and maximize water productivity. In contrast prolonged irrigation during sensitive growth stages may result in reduction in total yield. The application of water below the evapotranspiration requirements is termed deficit irrigation (DI).The objective of this research is to study the effect of deficit irrigation on yield and yield components of Sunflower (Hysun-33) hybrid. The experiment was conducted at Gezira Research Station, WadMedani, Sudan, in a randomized complete block design with three replications. In this study irrigation intervals every week (W) during all the season, 10 days interval (F1), 15 days interval (F2) and 20 days interval (F3) after flowering stage and 10 days interval (S1), 15 days interval (S2) and 20 days interval (S3) after seed formation stage - were applied to study the effect of full and deficit irrigation on yield and yield components of sunflower crop during the winter season 2011-2012. Results showed that water stress decreased the number of full seeds per head, weight of full seed and seed yield. The highest seed yield of $2810 \mathrm{~kg} \mathrm{ha}^{-1}$ was obtained from normal irrigation (W) and lowest of $1880 \mathrm{~kg} \mathrm{ha}^{-1}$ from irrigation every 20 days (S3). Results also indicated that there were no significant differences of water deficit on head diameter, plant height and stem diameter. Seasonal crop water applied measured were $17000,17400,16300,16500,16956,17042$, and $15655 \mathrm{~m}^{3} /$ ha for $\mathrm{W}, \mathrm{F} 1$, F2, F3, S1, S2 and S3 respectively. Apart from S3, the difference between the
\end{abstract}


highest (17400) and the lowest (16300) is about 6\%. However, water productivity showed large differences from the highest 0.17 of $\mathrm{W} 1$ and the lowest 0.12 of S3. The small difference in water applied in 13 irrigations and 11 irrigations is due to the unique characteristics of Gezira clay, no deep percolation and evaporation from cracks.

Keywords: water productivity, irrigation treatment, sunflower, water deficit, flowering stage, plant height, yield components, crop water.

\section{Introduction}

Sunflower (Helianthus annuus L.) is a drought adapted crop with a short growing season that requires relatively low irrigation requirements and makes it ideal for areas with limited irrigation supplies. It is an important oil crop of the world as well as in Sudan. It is a new edible oil crop in Sudan. The seeds have a high oil content (40-50\%) and 30\% digestible protein and can thus be used as a source of food for humans or as a poultry feed. Sunflower cake can be made as animal feed. It can be cultivated in winter under irrigation as a winter crop and in the rain season as a summer crop. Although experimentation on sunflower in Sudan started as early as the 1940 s, real concern with its commercial production started late mainly as a rainfed crop. In recent years, however, some rainfed areas have experienced significant drought. This led to shifting sunflower cultivation to irrigated areas. For this reason determining crop water requirement and water productivity under irrigated agriculture is essential for planning and water resources management. In the future irrigation management will emphasize to maximize the production per consumed unit of water, the water productivity, rather than maximize yield per unit of area in the irrigated agriculture under water scarcity.

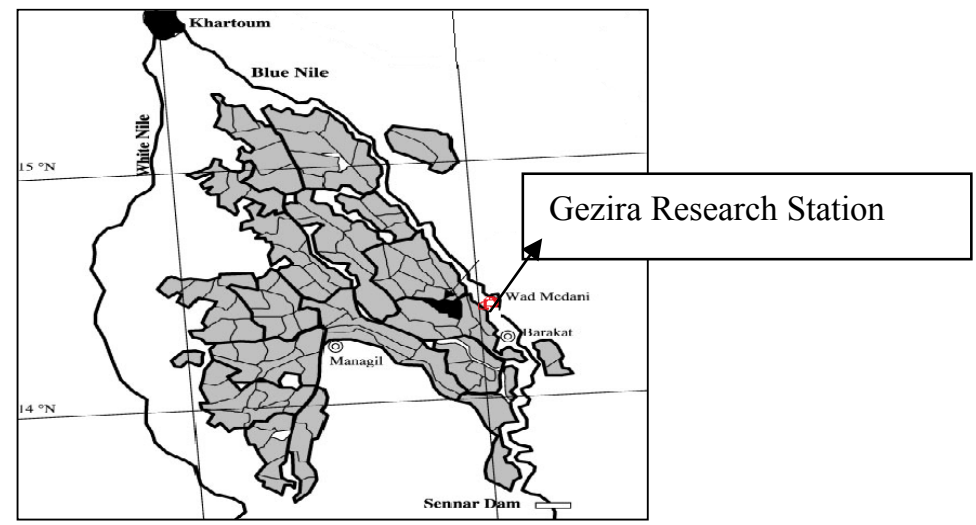

Figure 1: The location of the Gezira research station. Source: adapted from Abdelhadi [6]. 
Table 1: $\quad$ Mean Monthly climatic data of Gezira Research Station (2007).

\begin{tabular}{||l|r|r|r|r|r||}
\hline \multicolumn{1}{|c|}{ Month } & $\begin{array}{c}\text { Max.Temp } \\
\left({ }^{\circ} \mathrm{C}\right)\end{array}$ & $\begin{array}{c}\text { Min. Temp } \\
\left({ }^{\circ} \mathrm{C}\right)\end{array}$ & \multicolumn{1}{c|}{$\begin{array}{c}\text { RH } \\
(\%)\end{array}$} & $\begin{array}{c}\text { Sunshine } \\
(\mathrm{h})\end{array}$ & $\begin{array}{c}\text { Windspeed } \\
(\mathrm{m} / \mathrm{s})\end{array}$ \\
\hline January & 31.1 & 13.0 & 37.0 & 10.3 & 2.2 \\
\hline February & 35.4 & 15.5 & 29.6 & 10.4 & 2.2 \\
\hline March & 39.4 & 20.1 & 29.3 & 10.5 & 2.4 \\
\hline April & 41.5 & 22.9 & 24.3 & 10.9 & 2.3 \\
\hline May & 42.8 & 25.8 & 29.6 & 9.7 & 2.3 \\
\hline June & 40.1 & 25.1 & 54.0 & 8.4 & 4.0 \\
\hline July & 33.5 & 22.6 & 79.0 & 6.0 & 3.4 \\
\hline August & 34.1 & 22.4 & 77.5 & 6.2 & 2.5 \\
\hline September & 35.7 & 22.1 & 71.7 & 8.4 & 2.0 \\
\hline October & 38.6 & 23.0 & 59.0 & 8.8 & 1.5 \\
\hline November & 38.3 & 20.5 & 47.1 & 10.3 & 1.6 \\
\hline December & 36.2 & 17.7 & 34.0 & 10.3 & 2.0 \\
\hline
\end{tabular}

(Source: WadMedani Meteorological Station (2007).

Table 2: $\quad$ Volume weight of Gezira clay.

\begin{tabular}{|l|l|l|l|l|l|}
\hline $\begin{array}{l}\text { Moisture } \\
\text { content } \\
(\%)\end{array}$ & $\begin{array}{l}0-40 \\
(\mathrm{~cm})\end{array}$ & $\begin{array}{l}40-60 \\
(\mathrm{~cm})\end{array}$ & $\begin{array}{l}60-80 \\
(\mathrm{~cm})\end{array}$ & $\begin{array}{l}80-100 \\
(\mathrm{~cm})\end{array}$ & $\begin{array}{l}100-200 \\
(\mathrm{~cm})\end{array}$ \\
\hline $45-55$ & 1.11 & 1.13 & n.o & n.o & n.o \\
\hline $35-45$ & 1.15 & 1.14 & 1.25 & 1.29 & 1.30 \\
\hline $25-35$ & 1.19 & 1.26 & 1.32 & 1.38 & 1.40 \\
\hline $15-25$ & 1.23 & 1.32 & 1.46 & 1.53 & 1.54 \\
\hline $5-15$ & 1.25 & 1.35 & 1.53 & n.o & n.o \\
\hline
\end{tabular}

n.o: Not observed in the field. Source: Farbrother [7].

Table 3: Analysis of N, K and $\mathrm{P}$ in stem and leaves for all plants in each replicate.

\begin{tabular}{|l|l|l|l|}
\hline Analysis & $\mathrm{N} \%$ & $\mathrm{~K} \%$ & $\mathrm{P} \%$ \\
\hline R1 leaves & 1.8 & 0.20 & 0.253 \\
\hline R2 leaves & 1.7 & 0.19 & 0.215 \\
\hline R3 leaves & 2.0 & 0.20 & 0.222 \\
\hline R1 stem & 0.5 & 0.13 & 0.035 \\
\hline R2 stem & 0.4 & 0.17 & 0.024 \\
\hline R3 stem & 0.4 & 0.20 & 0.042 \\
\hline
\end{tabular}


Water stress, particularly at the flowering stage, reduces fertilization and seed set due to dehydration of pollen grains. More studies were focused on the effect of drought in sunflower yield Stone et al. [1] and Karam et al. [2]. Also water stress at the flowering stage was observed to be a limiting factor for seed filling, so significant reduction of unfilled seeds was observed as a result of under irrigation. D'Andria et al. [3] concluded that yield components of sunflower were affected by irrigation treatments. Many researchers stated that an irrigation interval of 7 days in sunflower improved grain yield, oil yield and water productivity (Yagoub et al. [4] and Faisal et al. [5]). Therefore, knowledge of the effects on sunflower production and water productivity under water stress conditions is becoming increasingly important. Irrigation scheduling is particularly important since many field crops are more sensitive to water deficit at specific phonological stages.

\subsection{Study area}

Experiment was conducted in the Gezira Research Station Farm, longitude $14^{\circ} .4$ $\mathrm{N}, 33^{\circ} 5 \mathrm{E}, 405 \mathrm{~m}$ (amsl). In particular, the soil of the study area is a deep, heavy soil (Vertisols) with $58-66 \%$ clay, $0.05 \%$ organic matter, a water infiltration rate of $1 \mathrm{~mm} \mathrm{~h}^{-1}$ and $\mathrm{pH}$ of 8.5 . Table 4 shows the mean monthly weather parameters from WadMedani Metrological Station.

Table 4: The effect of water intervals on plant height, head and stem diameter, number of full seed/ head, weight of full seed, total yield and water productivity.

\begin{tabular}{|c|c|c|c|c|c|c|c|}
\hline $\begin{array}{c}\text { Irrigation } \\
\text { Treatments }\end{array}$ & $\begin{array}{c}\text { Plant } \\
\text { height } \\
(\mathrm{cm})\end{array}$ & $\begin{array}{c}\text { Head } \\
\text { diameter } \\
(\mathrm{cm})\end{array}$ & $\begin{array}{c}\text { Stem } \\
\text { diameter } \\
(\mathrm{cm})\end{array}$ & $\begin{array}{c}\text { Number } \\
\text { of full } \\
\text { seed }\end{array}$ & $\begin{array}{c}\text { Weight } \\
\text { of full } \\
\text { seed } \\
(\mathrm{kg} / \mathrm{ha})\end{array}$ & $\begin{array}{c}\text { Total } \\
\text { yield } \\
(\mathrm{kg} / \mathrm{ha})\end{array}$ & $\begin{array}{c}\text { Water } \\
\text { Productivity } \\
\left(\mathrm{Kg} \mathrm{m}^{-3}\right)\end{array}$ \\
\hline $\mathrm{W}$ & 153 & 20 & 2.0 & 993 & 176 & 2,810 & 0.17 \\
\hline F1 & 153 & 19 & 2.0 & 969 & 176 & 2,670 & 0.15 \\
\hline F2 & 150 & 19 & 2.0 & 918 & 169 & 2,270 & 0.14 \\
\hline F3 & 151 & 19 & 2.1 & 851 & 150 & 2,150 & 0.13 \\
\hline S1 & 152 & 22 & 2.2 & 1068 & 211 & 2,670 & 0.15 \\
\hline S2 & 155 & 20 & 2.1 & 976 & 172 & 2,300 & 0.14 \\
\hline S3 & 150 & 19 & 2.0 & 950 & 167 & 1,880 & 0.12 \\
\hline
\end{tabular}

\section{Materials and methods}

Experimental research was conducted at Gezira Research Station farm, WadMedani-Sudan. All agronomic practices were conducted. Sunflower, variety Hysun 33 was sown in the second week of November 2011. The seed rate was 3 seeds per hole at $30 \mathrm{~cm}$ spacing between holes on top of $80 \mathrm{~cm}$ ridges, and then thinned one plant per hole after two weeks. The experimental design adopted was randomized complete block. Nitrogen was applied in the form of Urea 
$(46 \% \mathrm{~N}) 86 \mathrm{~kg} \mathrm{~N} \mathrm{ha}^{-1}$ in two split doses, one with the second irrigation and the rest of the nitrogen was applied at flowering as recommended in Gezira scheme. The plot size was $50 \mathrm{~m}^{2}(10 \mathrm{~m} * 5 \mathrm{~m})$ and $80 \mathrm{~cm}$ between rows. After planting the field was irrigated once every week up to the flowering stage and then on the basis of water deficit at three levels. Weeding was made by hand after third irrigation and repeated four times during the whole season. The gravimetric soil sampling method was used to measure soil moisture content at five soil depths $(0-20,20-40,40-60,60-80$ and $80-100 \mathrm{~cm})$ during the growing season. Four soil samples per plot were taken, The irrigation treatments were seven irrigated by furrow method including every week (W), 10 days interval (F1),15 days interval (F2) and 20 days interval (F3) after flowering stage until maturity and 10 days interval (S1), 15 days interval (S2) and 20 days interval (S3) after milking stage until maturity replicated three times. The amount of water applied was measured using a current meter in each treatment during the whole season. Climatic data were collected from the vicinity meteorological station in WadMedani. Five plant samples were taken to measure the different plant parameters such as plant height $(\mathrm{cm})$, head diameter and stem diameter $(\mathrm{cm})$ (after flowering stage and immediately before maturity), number of seed per head and weight of full seed, and total yield and biomass (kg/ha) after harvesting. Harvesting was done on 8th of March. Data were statistically analyzed by Statistix 9.0 software (www.statistix.com)

Soil moisture contents were monitored prior to irrigation throughout the season using the gravimetric method from the plots of the second replication of the various treatments and values were converted to volumetric water content using bulk density for each depth. According to measure of the soil water contents, the plots of the treatment were irrigated from the initial soil moisture content of $0-100 \mathrm{~cm}$ soil layer to $\mathrm{FC}$. In the study area runoff and deep percolation were negligible due to clay soil characteristics and were taken as zero in the water balance equation as follows

$$
\mathrm{ET}=\Delta \mathrm{S}+\mathrm{I}
$$

where ET is evapotranspiration, I: irrigation. $\Delta \mathrm{S}$ is change in soil moisture content in the soil profile. Thus between two irrigation $\mathrm{I}=0$ and thus $\mathrm{ET}=\Delta \mathrm{S}$. Therefore ET is determined from the change in soil moisture.

\section{Results and discussion}

The analysis data of head and stem diameter, plant height, number of full seed, weight of seed per head and total yield as affected by different irrigation frequencies are presented in table 4 . Results showed that the water treatments had significant effect on number of seed per head, weight of full seed and total yield. Seed yield of sunflower hybrid decreased as irrigation intervals increased. Results are supported by the findings of Iraj et al. [8], who reported that increase in the irrigation intervals reduced seed yield, seed number per head. Faisal et al. [5] examined effect of three irrigation intervals (7,14 and 21 days) on seed and oil yields of a sunflower, he found that sunflower was sensitive to the long 
irrigation intervals and the reduction in seed and oil yields under prolonged irrigation was associated with significant reduction in yield components. He also found prolonged irrigation decreased the mean 1000-seed weight. Yagoub et al. [4] reported that the long period of water deficit at sensitive growth stages causes significant reduction in seed yield. The results also are in the line with the findings of Human et al. [9] which showed that water stress in stages of flowering, seed formation and grain filling in sunflower caused the most reduction of grain yield. Table 3 show the analysis of $\mathrm{N}, \mathrm{k}, \mathrm{P}$ in the stem and leaves of plant for all treatments mixed in one sample per rep i.e. rep1, rep 2 and rep 3. The result showed that no different in $\mathrm{N}, \mathrm{K}$, and $\mathrm{P}$ percentage in the stem and leaves between reps, i.e. water intervals did not affect in NPK content in plant.

\subsection{Plant height}

Under different irrigation treatments the average plant height ranged between 150 and $155 \mathrm{~cm}$. This result shows that there are no differences between treatments i.e. plant heights were not affected by water deficit after flowering stage. The highest plant height was observed in treatment (S2) and lowest one in treatment (F2) and (S3).

\subsection{Head diameter}

Ali and Talukder [10] stated that the deficit irrigation had effect on head diameter. Roshdi et al. [12] showed that with increasing irrigation intervals and applying water stress the head diameter and seed yield decreased. In this study there were significant difference between irrigation treatments, however, irrigation at 10 day intervals after seed formation stage (S2) showed highest head diameter $(22 \mathrm{~cm})$. The results is in the way with the findings of Ghani et al. [11] which indicated that the irrigation intervals had a significant effect on this parameter.

\subsection{Stem diameter}

At the field condition one of the effects of low water availability is the reduction of stem diameter due to lower radius growth of stem. In this study there were non- significant differences in stem diameter between treatments due to water stress started after flowering stage

\subsection{Seeds number per head}

Under water stress condition, plants do not absorb enough water and then the seeds are more or less unfilled. Roshdi et al. $[12,13]$ reported that when water stress occurred, particularly during flowering, head diameter decreased and as a result the number of filled grains decreased. In this study there were significant differences between irrigation treatments, the highest number was observed in 10 days irrigation interval (S1) and the lowest was in irrigation every 20 days (F3). Highest total yield $(2810 \mathrm{~kg} / \mathrm{ha})$ was observed in treatment irrigation every week 
and the lowest yield in treatment 20 day intervals after seed formation (S3) was (1880 kg/ha).

\subsection{Irrigation water applied}

Amount of water applied in irrigation cycles to each treatment plots were measured by a current meter, are presented in table 5. The results showed that treatment F1 has highest water amount $17405 \mathrm{~m}^{3} /$ ha compared to other treatments and S3 has the lowest water amount $15655 \mathrm{~m}^{3} /$ ha. Fig 2 shows the water applied during all the season to treatment $\mathrm{W}, \mathrm{F} 1, \mathrm{~F} 2$ and F3 respectively. However, the difference between all treatments except S3 was within 6\%. Even $\mathrm{S} 3$ is only about $8 \%$ less than the weekly irrigation although S3 had only 11 irrigations: two irrigations less. This small difference is due to the unique characteristic of Gezira clay: no deep percolation over irrigation is limited. Also as the irrigation intervals increases evaporation from cracks increases. The different between 13, 11 and 8 irrigations is about $880 \mathrm{~m}^{3} /$ ha while two irrigations are equivalent to $2600 \mathrm{~m}^{3} /$ ha. The average water added per irrigation is $1300-1400 \mathrm{~m}^{3} /$ ha. If we subtract the first irrigation which about double the normal irrigation, about $2400 \mathrm{~m}^{3} / \mathrm{ha}$, the average irrigation is about $1100-1200 \mathrm{~m}^{3} /$ ha. This is about $460-500 \mathrm{~m}^{3} /$ Feddan, which is higher than the well known average in Gezira which is $420 \mathrm{~m}^{3} /$ Feddan (Feddan $=0.42 \mathrm{ha}$ ).

Table 5: The amount of water applied during the season in $\left(\mathrm{m}^{3} / \mathrm{ha}\right)$.

\begin{tabular}{|c|c|c|c|}
\hline Treatment & $\begin{array}{c}\text { Amount of water } \\
\left(\mathrm{m}^{3} / \mathrm{ha}\right)\end{array}$ & $\begin{array}{c}\text { Irrigation- } \\
\text { average }\end{array}$ & No of irrigations \\
\hline W & 17018 & 1300 & 13 \\
\hline F1 & 17405 & 1450 & 12 \\
\hline F2 & 16287 & 1480 & 11 \\
\hline F3 & 16488 & 1490 & 11 \\
\hline S1 & 16956 & 1410 & 12 \\
\hline S2 & 17042 & 1420 & 12 \\
\hline S3 & 15655 & 1420 & 11 \\
\hline
\end{tabular}

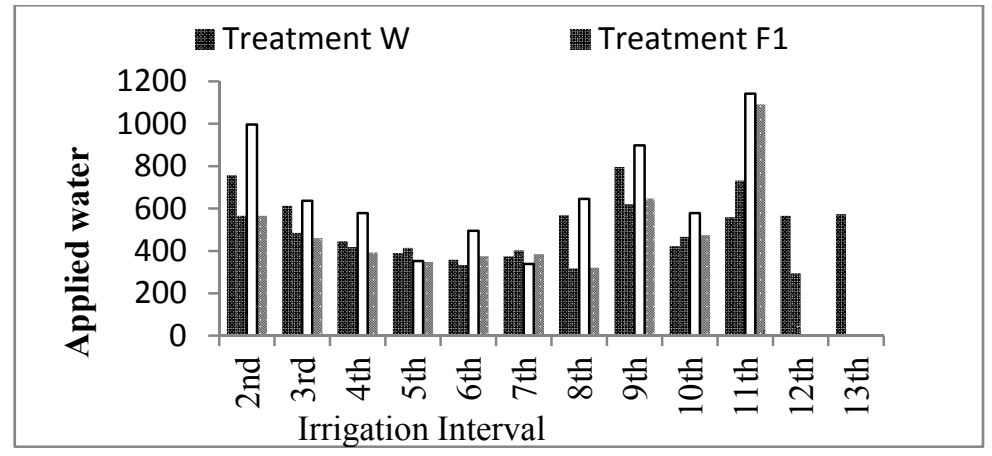

Figure 2: $\quad$ Irrigation water applied for all treatments W, F1, F2 and F3. 


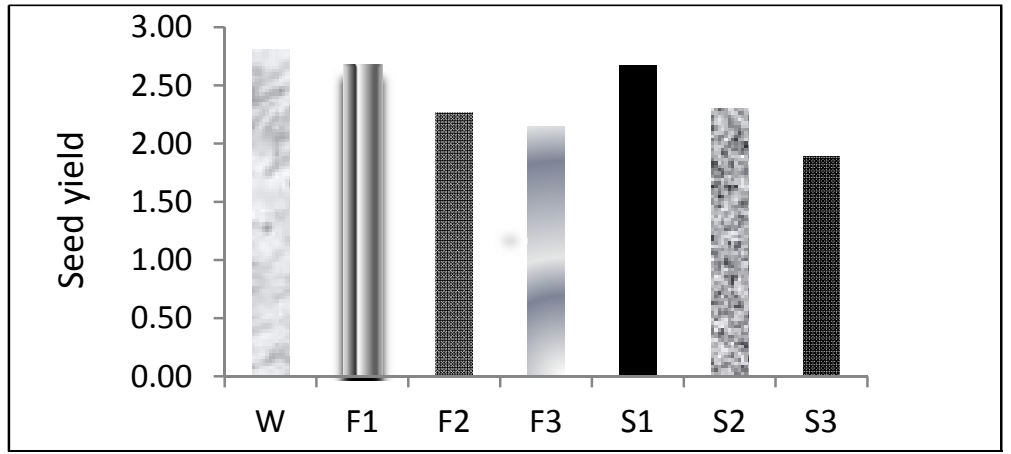

Figure 3: $\quad$ Total seed yield response to total water applied.

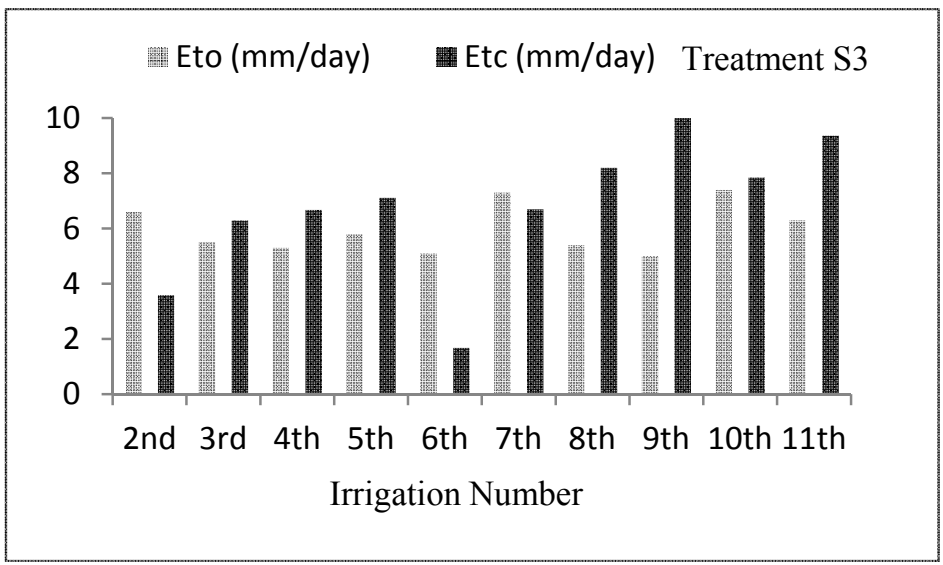

Figure 4: $\quad$ Seasonal ETc and ETo for two treatments F3 and S3.

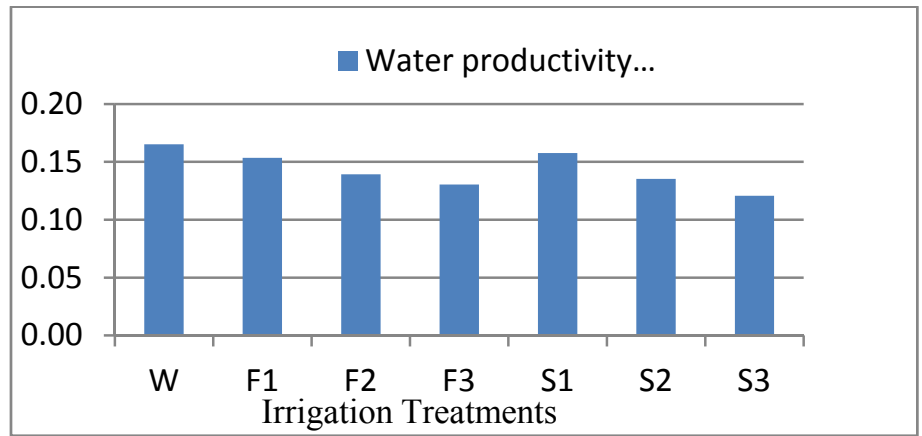

Figure 5: Water productivity for each irrigation treatments in $\left(\mathrm{kg} \mathrm{m}^{-3}\right)$. 


\subsection{Water productivity (WP) $\left(\mathrm{kg} \mathrm{m}^{-3}\right)$}

Highest WP is $\left(0.17 \mathrm{~kg} \mathrm{~m}^{-3}\right)$ for weekly irrigation and the lowest is $\left(0.12 \mathrm{~kg} \mathrm{~m}^{-3}\right)$ for S3 and F3 $\left(0.12\right.$ and $\left.0.13 \mathrm{~kg} \mathrm{~m}^{-3}\right)$. Next highest is $\mathrm{F} 1$ and $\mathrm{S} 1\left(0.15 \mathrm{~kg} \mathrm{~m}^{-3}\right)$ then F2 and S2 $\left(0.14 \mathrm{~kg} \mathrm{~m}^{-3}\right)$. The trend is very clear Fig 5 . However the water productivity for the weekly irrigation is low compared to that of wheat in Gezira under good management which is about $0.3 \mathrm{~kg} \mathrm{~m}^{-3}$ but similar to farmers average of $0.17 \mathrm{~kg} \mathrm{~m}^{-3}$.

\section{Conclusion}

Referring to when and how much to irrigate, irrigation water management has an important role at farm level. Increasing water productivity may be the best way to achieve efficient water use. The results obtained strongly suggest that an irrigation interval of 10 days is optimum for reasonable sunflower production in Gezira irrigated scheme. This result indicated that flowering stage is critical stage sensitive to water deficit. To improve WP for sunflower more study is needed to indicate the critical stages that reduce yield due to water stress. Sunflower seed is expected to increase with water use up to a maximum yield potential Demir et al. [14] and Payero et al. [15]. In this study the results showed that in Gezira clay soil irrigation every week does not result in more consumption of water and irrigation every 15 days and 20 days do not save water. In preparation to the number of irrigation saved. This is because there is no deep drainage, so frequent irrigation does not mean more water use, and crack in long irrigation intervals increased evaporation and so more water per irrigation.

\section{Reference}

[1] Stone LR SA, Gwin RE, Khan AH (1996) Response of corn, grain sorghum and sunflower to irrigation to the High Plains of Kansas. Agric Water Manage 30: 251-259.

[2] Karam F , Lahoud R , Masaad R , Kabalan R , Breidi J , Chalita C and Rouphael Y (2007) Evapotranspiration, seed yield and water use efficiency of drip irrigated sunflower under full and deficit irrigation conditions. Agricultural Water Management 90: 213-223.

[3] D'Andria R. CF, Magliulo V, and Mori M. (1995) Yield and soil water uptake of sunflower sown in spring and summer. agron J 87: 1122-1128.

[4] Yagoub S , Osman A and Abdesalam A (2010) Effect of Watering Intrvals and Weeding on Growth and Yield of Sunflower (Helianthus annuus 1). Journal of Science and Technology 11:2.

[5] Faisal E, Ahmed., B. E. A. M. A. and Mahmoud. F. Ahmed. (2006) Effect of Irrigation Interval and Planting Density on Seed and Oil Yields of Sunflower Hybrid. U of K J Agric Sci 14: 343-353.

[6] Abdelhadi, A.W., 2002, Agricultural Research Corporation ARC annual report: Land and Water Research Center. Wad Medani, Sudan. 
[7] Farbrother H (1996) Water Management Options in Sudan Gezira: A Review. Chatham, UK: Natural Resources Institute.

[8] Iraj Alahdadi HO, Fataneh Parhizkar khajani (2011) Effect of water stress on yield and yield componenets of Sunflower hybrids. African Journal of Biotechnology 10: 6504-6509

[9] Human, J. J., D. Dutoit., H. D. Benzuid Enhout, and L. P. Bruyn (1998). The influence of plant water stress on net photosynthesis and yield of Sunflower. Agriculttural University of South Africa. Crop Science. 164(4): 231-241.

[10] Ali MH and Talukder MSU (2008) Increasing water productivity in crop production-A synthesis. Agricultural Water Management 95: 1201-1213.

[11] Ghani A , Hussain M and Qureshi MS (2000) Effect of different irrigation regimens on the growth and yield of sunflower. Int $\mathbf{J}$ of Agri and Biol 2: 334-335.

[12] Roshdi, M., H. Heydari Sharifabad, M. Karimi, GH. Nourmohammadi and F. Darvish (2006). A Syrvey on the impact of water deficiency over the yield of sunflower seed cultivar and its components. J. Agri. Sci. 12(1): 109-121.

[13] Roshdi, M., S. Rezadoost, and H. Zainalzade. 2005. Asurvey on the effect of different levels of irrigation features on the qualitative and quantitative varieties of sunflower. Rome, Italy. pp: 82.

[14] Demir, A., A. Göksoy, H. Büyükcangaz, Z. Turan, and E. Köksal. 2006. Deficit irrigation of sunflower (Helianthus annuus L.) in a sub-humid climate. Irrigation Science 24(4): 279.

[15] Payero, J. O., S. R. Melvin, and S. Irmak. 2005. Response of soybean to deficit irrigation in the semi-arid environment of West-Central Nebraska. Transactions of the ASAE 48(6): 2189-2203. 